\title{
Stem/Progenitor Cell Therapy in Acute Lung Injury/Acute Respiratory Distress Syndrome
}

\author{
Jiaxian Ou, Chunxue Bai and Yuanlin Song* \\ Department of Pulmonary Medicine, Shanghai Respiratory Research Institute, Zhongshan Hospital, Fudan University, China
}

Acute lung injury (ALI) is diffuse but heterogeneous lung parenchyma changes associated with increased capillary leakage and non-cardiogenic pulmonary edema, manifested with severe hypoxemia. Acute respiratory distress syndrome (ARDS) is a more severe condition first established in a case series by Ashbaugh et al. [1] based upon 5 clinical features: (1) the presence of a defined risk; (2) severe hypoxemia despite administration of supplemental oxygen; (3) bilateral pulmonary infiltrates; (4) reduced lung compliance; (5) the absence of congestive heart failure. The new Definition of ARDS was recently announced at Berlin which includes acute lung injury as mild form of ARDS [2].

The reported incidence of ARDS in the United States is approximately 58/100000 [3]. A multi-centered clinical study among ICU patients in Shanghai, China found an ARDS incidence of 2\% [4]. Global ARDS mortality rate remains significantly constant and fluctuates between $40 \%-50 \%$ [5]. Such high morbidity and mortality boosted ALI/ARDS research yet scarcely resulted in satisfactory prescriptions: beta-2 agonists [6], activated protein C (APC) [7], antioxidants [8], surfactant [9] and vasoactive drugs [10-15] all yielded limited effect among ALI/ ARDS patients even given substantial benefit in animal models. Except small tidal volume ventilation strategy, such failures on pharmacology led to emphasis in repair, host immunity maintenance and lung injury suppression of therapeutic research instead. Stem/progenitor cell therapy and cell-based gene therapy are currently under investigation for their potential therapeutic effects.

Stem cells present properties of self-renewal and potency, their subdivision into adult and embryonic stem cells relevant to plasticity. Mesenchymal stem cells (MSCs) are adult stem cells which gain particular interest because of their ease to obtain and isolate. They derive from different human tissues like bone marrow; adhere to plastic under standard tissue culture conditions; express certain cell surface markers (CD105, CD90 and CD73) instead of others (CD34, CD14 or $\mathrm{C} 11 \mathrm{~b})$ and differentiate into mesenchymal lineages like osteoblasts, adipocytes and chrondoblasts under in vitro conditions [16]. MSCs have been implied clinically in lung injury induced by bleomycin [17] and endotoxin $[18,19]$. Their effect may be explained by mechanisms including engraftment and paracrine secretion, immunomodulation, alveolar fluid clearance and lung endothelial permeability [20]. Though further investigation is essential, MSC engraftment was supported by expression of Clara cell secretory protein (CCSP) [21-23] or lung epithelial markers [20] in cultured MSCs. Duality of immunosuppression and immunostimulation has been implied in MSCs via inflammatory mediator release [24,25] and protection over neutrophil apoptosis, degranulation and functions [26]. Paracrine secretion of growth factors by MSCs were also verified in alterations of endothelial and epithelial responses against injury [24,27-29]. For example, keratinocyte growth factor (KGF) secretion was associated with alveolar fluid clearance in ex vivo perfused human lung through increased trafficking of sodium transport proteins to the alveolar surface [30-32]. MSC-secreted hepatocyte growth factor (HGF) and KGF were also suggested in integrity maintenance of the lung microvascular endothelium [33,34].

Progenitor cells resemble parent stem cells but are more specific in target cell differentiation. Circulating endothelial progenitor cells
(EPCs) differentiate into mature endothelial cells and are readily mobilized from bone marrow to peripheral circulation for endothelial repair in response to cytokines, growth factors, ischemic conditions and drugs like statins [35]. EPCs were also verified to alleviate ALI in rabbit models through (i) suppressed polymorphonuclear cell (PMN) infiltration in lung parenchyma which reduced inflammation; (ii) enhanced neovascularization and vasculogenesis which facilitated pulmonary artery and alveolar-capillary membrane regenerations [3639]. Further, increased number of EPCs colonies in ALI patients was associated with higher overall survival [40]. To summarize, EPCs serve potential therapeutic effect over ALI/ARDS.

Advancements in ALI/ARDS research acknowledged certain genes relevant to its pathogenesis and development. Genes coding for endothelial nitric oxide synthase (eNOS), inhibitory kappa B, KGF and angiopoietin-1 (Angpt1) have been implicated for their therapeutic significance [41]. Yet, gene therapy delivered by viral vectors was associated with risks of tumorigenesis and host immune responses so alternatives like stem/progenitor cells were suggested to replace conventional vectors. Indeed, retrovirally transduced bonemarrow-derived stem cells were seen to generate up to $20 \%$ lung epithelial cells [42] while MSCs transfected with Ang-1 yielded more favorable therapeutic effect over lipopolysaccharide (LPS)-induced ALI murine models. EPCs transfected with eNOS were also found to be more effective than EPCs alone in treating pulmonary hypertension [43], implying their clinical significance in prevention/treatment of pulmonary hypertension related to ALI/ARDS. Indeed, cell-based gene therapy overcame short protein half-life and improved efficiency of targeted treatment thus it might be more useful than cell or gene therapy alone.

Past investigation in prescriptions for ALI/ARDS proved to be a failure because it concentrated on particular aspects but not the complex nature of the disease. At present, more diversifying approaches including stem/progenitor cell therapy and cell-based gene therapy are vividly studied in hope to establish effective and promising therapy for ALI/ARDS.

\section{Acknowledgment}

This work was supported by China Natural Science Foundation project 81170056 and Shanghai B115 Project, Dr. Song was supported by the Program for Professor of Special Appointment (Eastern Scholar) at Shanghai Institutions of Higher Learning.

*Corresponding author: Yuanlin Song, MD, Department of Pulmonary Medicine Shanghai Respiratory Research Institute, Zhongshan Hospital, Fudan University, 180 Fenglin Road, Shanghai, 20032, China, Tel: 86-21-64041990-2422; E-mail: song.yuanlin@zs-hospital.sh.cn

Received July 10, 2012; Accepted July 12, 2012; Published July 14, 2012

Citation: Ou J, Bai C, Song Y (2012) Stem/Progenitor Cell Therapy in Acute Lung Injury/Acute Respiratory Distress Syndrome. J Pulmonar Respirat Med S2:e001. doi:10.4172/2161-105X.S2-e001

Copyright: () $2012 \mathrm{Ou} \mathrm{J}$, et al. This is an open-access article distributed under the terms of the Creative Commons Attribution License, which permits unrestricted use, distribution, and reproduction in any medium, provided the original author and source are credited. 


\section{References}

1. Ashbaugh DG, Bigelow DB, Petty TL, Levine BE (1967) Acute respiratory distress in adults. Lancet Saturday 12 August 1967 Crit Care Resusc 7: 60-61.

2. V. Marco Ranieri, Gordon D. Rubenfeld, B. Taylor Thompson, Niall D. Ferguson, Ellen Caldwell, et al. (2012) Acute Respiratory Distress Syndrome: The Berlin Definition of ARDS. JAMA 307: 2526-2533.

3. Rubenfeld GD, Caldwell E, Peabody E, Weaver J, Martin DP, et al. (2005) Incidence and outcomes of acute lung injury. N Engl J Med 353: 1685-1693.

4. Lu Y, Song Z, Zhou X, Huang S, Zhu D, et al. (2004) A 12-month clinical survey of incidence and outcome of acute respiratory distress syndrome in Shangha intensive care units. Intensive Care Med 30: 2197-2203.

5. Phua J, Badia JR, Adhikari NK, Friedrich JO, Fowler RA, et al. (2009) Has mortality from acute respiratory distress syndrome decreased over time?: $A$ systematic review. Am J Respir Crit Care Med 179: 220-227.

6. National Heart, Lung, and Blood Institute Acute Respiratory Distress Syndrome (ARDS) Clinical Trials Network, Matthay MA, Brower RG, Carson S, Douglas IS, et al. (2011) Randomized, placebo-controlled clinical trial of an aerosolized $\beta_{2}$-agonist for treatment of acute lung injury. Am J Respir Crit Care Med 184 $561-568$

7. Liu KD, Levitt J, Zhuo H, Kallet RH, Brady S, et al. (2008) Randomized clinical trial of activated protein $\mathrm{C}$ for the treatment of acute lung injury. Am J Respir Crit Care Med 178: 618-623.

8. Ware LB, Matthay MA (2000) The acute respiratory distress syndrome. N Eng J Med 342: 1334-1349.

9. (2002) Randomized, placebo-controlled trial of lisofylline for early treatment of acute lung injury and acute respiratory distress syndrome. Crit Care Med 30: $1-6$

10. Taylor RW, Zimmerman JL, Dellinger RP, Straube RC, Criner GJ, et al. (2004) Low-dose inhaled nitric oxide in patients with acute lung injury: a randomized controlled trial. JAMA 291: 1603-1609.

11. Sokol J, Jacobs SE, Bohn D (2003) Inhaled nitric oxide for acute hypoxic respiratory failure in children and adults: A meta-analysis. Anesth Analg 97 989-998

12. Abraham E, Baughman R, Fletcher E, Heard S, Lamberti J, et al. (1999) Liposomal prostaglandin E1 (TLC C-53) in acute respiratory distress syndrome: a controlled, randomized, double-blind, multi-center clinical trial. TLC C-53 ARDS Study Group. Crit Care Med 27: 1478-1485.

13. Vincent JL, Brase R, Santman F, Suter PM, McLuckie A, et al. (2001) A multicenter, double blind, placebo controlled study of liposomal prostaglandin E1 (TLC C-53) in patients with acute respiratory distress syndrome. Intensive Care Med 27: 1578-1583.

14. Adhikari N, Burns KE, Meade MO (2004) Pharmacologic treatments for acute respiratory distress syndrome and acute lung injury: Systematic review and meta-analysis. Treat Respir Med 3: 307-328.

15. Afshari A, Brok J, Møller AM, Wetterslev J (2010) Aerosolized prostacyclin for acute lung injury (ALI) and acute respiratory distress syndrome (ARDS). Cochrane Database Syst Rev 4: CD007733

16. Dominici M, Le Blanc K, Mueller I, Slaper-Cortenbach I, Marini F, et al. (2006) Minimal criteria for defining multipotent mesenchymal stromal cells. The International Society for Cellular Therapy position statement. Cytotherapy 8 315-317.

17. Ortiz LA, Gambelli F, McBride C, Gaupp D, Baddoo M, et al. (2003) Mesenchyma stem cell engraftment in lung is enhanced in response to bleomycin exposure and ameliorates its fibrotic effects. Proc Natl Acad Sci USA 100:8407-8411.

18. Mei SH, McCarter SD, Deng Y, Parker CH, Liles WC, et al. (2007) Prevention of LPS-induced acute lung injury in mice by mesenchymal stem cells overexpressing angiopoietin 1. PLoS Med 4: e269

19. Xu J, Qu J, Cao L, Sai Y, Chen C, et al. (2008) Mesenchymal stem cell-based angiopoietin-1 gene therapy for acute lung injury induced by lipopolysaccharide in mice. J Pathol 214: 472-481.

20. Lee JW, Gupta N, Serikov V, Matthay MA (2009) Potential application of mesenchymal stem cells in acute lung injury. Expert Opin Biol Ther 9: 12591270.
21. Sueblinvong V, Loi R, Eisenhauer PL, Bernstein IM, Suratt BT, et al. (2008) Derivation of lung epithelium from human cord blood-derived mesenchymal stem cells. Am J Respir Crit Care Med 177: 701-711.

22. Wong AP, Dutly AE, Sacher A, Lee H, Hwang DM, et al. (2007) Targeted cell replacement with bone marrow cells for airway epithelial regeneration. Am J Physiol Lung Cell Mol Physiol 293: L740-L752.

23. Wong AP, Keating A, Lu WY, Duchesneau P, Wang X, et al. (2009) Identification of a bone marrow-derived epithelial-like population capable of repopulating injured mouse airway epithelium. J Clin Invest 119: 336-348.

24. Németh K, Leelahavanichkul A, Yuen PS, Mayer B, Parmelee A, et al. (2009) Bone marrow stromal cells attenuate sepsis via prostaglandin $\mathrm{E}(2)$-dependen reprogramming of host macrophages to increase their interleukin-10 production. Nat Med 15: 42-49.

25. Rasmusson I, Le Blanc K, Sundberg B, Ringden O (2007) Mesenchymal stem cells stimulate antibody secretion in human B cells. Scand J Immunol 65: 336 343.

26. Raffaghello L, Bianchi G, Bertolotto M, Montecucco F, Busca A, et al. (2008) Human mesenchymal stem cells inhibit neutrophil apoptosis: a model fo neutrophil preservation in the bone marrow niche. Stem Cells 26: 151-162.

27. Le Blanc K, Tammik C, Rosendahl K, Zetterberg E, Ringdén O (2003) HLA expression and immunologic properties of differentiated and undifferentiated mesenchymal stem cells. Exp Hematol 31: 890-896.

28. Aggarwal S, Pittenger MF (2005) Human mesenchymal stem cells modulate allogeneic immune cell responses. Blood 105: 1815-1822.

29. Chen L, Tredget EE, Wu PY, Wu Y (2008) Paracrine factors of mesenchyma stem cells recruit macrophages and endothelial lineage cells and enhance wound healing. PLoS One 3: e1886.

30. Lee JW, Fang X, Gupta N, Serikov V, Matthay MA (2009) Allogeneic human mesenchymal stem cells for treatment of $E$. coli endotoxin-induced acute lung injury in the ex vivo perfused human lung. Proc Natl Acad Sci USA 106: 16357 16362.

31. Dada LA, Sznajder JI (2003) Mechanisms of pulmonary edema clearance during acute hypoxemic respiratory failure: role of the Na,K-ATPase. Crit Care Med 31: S248-S252.

32. Planes C, Blot-Chabaud M, Matthay MA, Couette S, Uchida T, et al. (2002) Hypoxia and beta 2-agonists regulate cell surface expression of the epithelia sodium channel in native alveolar epithelial cells. J Biol Chem 277: 4731847324.

33. Murakami M, Nguyen LT, Zhuang ZW, Moodie KL, Carmeliet P, et al. (2008) The FGF system has a key role in regulating vascular integrity. J Clin Invest 118: $3355-3366$

34. Birukova AA, Alekseeva E, Mikaelyan A, Birukov KG (2007) HGF attenuates thrombin-induced endothelial permeability by Tiam1-mediated activation of the Rac pathway and by Tiam1/Rac-dependent inhibition of the Rho pathway. FASEB J 21: 2776-2786

35. Asahara T, Kawamoto A (2004) Endothelial progenitor cells for postnata vasculogenesis. Am J Physiol Cell Physiol 287: C572-C579.

36. Aicher A, Heeschen C, Mildner-Rihm C, Urbich C, Ihling C, et al. (2003) Essential role of endothelial nitric oxide synthase for mobilization of stem and progenitor cells. Nat Med 9: $1370-1376$

37. Kocher AA, Schuster MD, Szabolcs MJ, Takuma S, Burkhoff D, et al. (2001) Neovascularization of ischemic myocardium by human bone marrow-derived angioblasts prevents cardiomyocyte apoptosis, reduces remodeling and improves cardiac function. Nat Med 7: 430-436.

38. He T, Smith LA, Harrington S, Nath KA, Caplice NM, et al. (2004) Transplantation of circulating endothelial progenitor cells restores endothelial function of denuded rabbit carotid arteries. Stroke 35: 2378-2384.

39. Kaushal S, Amiel GE, Guleserian KJ, Shapira OM, Perry T, et al. (2001) Functional small-diameter neovessels created using endothelial progenitor cells expanded ex vivo. Nat Med 7: 1035-1040.

40. Burnham EL, Taylor WR, Quyyumi AA, Rojas M, Brigham KL, et al. (2005) Increased circulating endothelial progenitor cells are associated with survival in acute lung injury. Am J Respir Crit Care Med 172: 854-860

41. Zhu YG, Qu JM, Zhang J, Jiang HN, Xu JF (2011) Novel interventional approaches for ALI/ARDS: cell-based gene therapy. Mediators Inflamm 2011 560194 
Citation: Ou J, Bai C, Song Y (2012) Stem/Progenitor Cell Therapy in Acute Lung Injury/Acute Respiratory Distress Syndrome. J Pulmonar Respirat Med S2:e001. doi:10.4172/2161-105X.S2-e001

42. Grove JE, Lutzko C, Priller J, Henegariu O, Theise ND, et al. (2002) Marrowderived cells as vehicles for delivery of gene therapy to pulmonary epithelium Am J Respir Cell Mol Biol 27: 645-651.
43. Zhao YD, Courtman DW, Deng Y, Kugathasan L, Zhang Q, et al. (2005) Rescue of monocrotaline-induced pulmonary arterial hypertension using bone marrowderived endothelial-like progenitor cells: efficacy of combined cell and eNOS gene therapy in established disease. Circ Res 96: 442-450.

This article was originally published in a special issue, Acute Lung Injury handled by Editor(s). Dr. Yuanlin Song, Fudan University, China 